\title{
Effect of vinasse (condensed molasses solubles) on performance, blood metabolites, ruminal parameters and carcass characteristics of Mahabadi goat male kids
}

\author{
A. Zali ${ }^{1,3}$, M. Eftekhari ${ }^{2}$, K. Pourasad ${ }^{1}$, M. Ganjkhanlou ${ }^{1}$, F. Fatehi ${ }^{1}$ and H. Zakaria Pour ${ }^{1}$ \\ 1 University of Tehran, College of Agriculture and Natural Resources, Department of Animal Science, Karaj, 31587-77871, Iran \\ ${ }^{2}$ Qazvin Agricultural and Natural Resources Education and Research Center of Qazvin, AREEO, Department of Animal Science \\ Qazvin, 34156-77566, Iran
}

KEY WORDS: molasses, fermentation, goats, growth, rumen

Received: 3 September 2018

Revised: 20 July 2019

Accepted: 21 November 2019
${ }^{3}$ Corresponding author: e-mail: a.zali@ut.ac.ir

\begin{abstract}
Thirty-two goat male kids (body weight $20 \pm 2 \mathrm{~kg}$; age $~ 5-6$ months) were used to examine the effects of vinasse supplementation on growth, carcass characteristics, and blood and ruminal parameters in a completely randomized design. Kids were randomly divided into four groups: control diet without vinasse (T1) and diets containing 4 (T2), 8 (T3) and 12\% (T4) of vinasse on dry matter (DM) basis. Dry matter intake (DMI) was recorded daily and animals were weighed every 21 days during the 90-day experimental period. Vinasse supplementation had no significant effect on DMI $(P=0.21)$, average daily gain $(P=0.61)$ and feed conversion ratio $(P=0.79)$. Adding vinasse to diets at high levels (T3 and T4) enhanced rumen $\mathrm{pH}(P=0.03)$; however, it had no effect on rumen ammonia nitrogen $(P=0.62)$ and volatile fatty acids concentration. Plasma metabolites concentrations were not affected by treatments except the magnesium level which increased in line with the level of vinasse $(P=0.03)$. Vinasse supplementation induced significant reduction of the internal fat weight in the T3 and T4 groups $(P=0.02)$, whereas hot carcass weight $(P=0.75)$, carcass yield $(P=0.81)$, longissimus muscle (LM) area $(P=0.97)$, backfat thickness $(P=0.68)$ and LM chemical composition (crude protein $(P=0.18)$, ether extract $(P=0.93)$ and ash percent $(P=0.21))$ were not affected. The obtained results may suggest that vinasse can be added into the goat kids diet up to $12 \%$ without any adverse effects on performance but with the potential to reduce the internal fat content.
\end{abstract}

\section{Introduction}

Nowadays, great social and environmental pressure is being exerted to reduce environmental pollution resulting from the production of agroindustrial by-products, and so countries are trying to adapt to this challenge by reutilizing them as animal feed (Tufarelli et al., 2013). Waste disposal and by-product management in food processing industry pose problems in the areas of environmental protection and sustainability (Russ and MeyerPittroff, 2004).

Vinasse (condensed molasses solubles, CMS) is an agro-industrial by-product of alcohol, citric acid, yeasts, monosodium glutamate and ephedrine production by fermentation of molasses (Karalazos and Swan, 1977; Stemme et al., 2005; LópezCampos et al., 2011). In the ethanol production 
process, 12 to 201 of vinasse are produced per litter of ethanol (Cazetta and Celligoi, 2006). Compared with molasses, vinasse is lower in sugar concentration, as the majority of sugar is consumed during fermentation process, while it is higher in ash and crude protein (CP) content. The main sources of CP in vinasse are none protein nitrogen (NPN) compounds mainly betaine and glutamic acid (Stemme et al., 2005); however, the true protein content remains low (Yalçın et al., 2010). In addition, potassium accounts for the majority of ash content (approximately one-third of beet-vinasse, up to $10.6 \%$ of dry matter (DM)) (Weigand and Kirchgessner, 1980).

Feeding food residue to livestock can be seen as an effective option for handling waste because it transforms an inedible material into high-quality food products, such as meat (Elferink et al., 2008), which can reduce the cost of nutrition while the profit of the producer is increased. Ruminants economically have an important role as converters of many agro-industrial by-products and recycling such materials to human edible foods and providing an additional source of income (Vasta et al., 2008; Tufarelli and Laudadio, 2011). The effect of adding vinasse has been studied in sheep (Karalazos and Swan, 1977; López-Campos et al., 2011) and cattle (Zali et al., 2017). When fed to sheep, vinasse increased feed conversion ratio (FCR) and rumen $\mathrm{pH}$ while carcass characteristics remained unchanged. Crude protein digestibility increased at high dosage of vinasse, similarly FCR was increased in feedlot growing calves fed vinasse, but apparent digestibility of nutrients and ruminal concentration of propionate were decreased as the level of vinasse increased to the level of $15 \%$.

However, the effect of vinasse remains unexplored in goats. Goat is a ruminant which is considered resistant to environmental and nutritional harshness, which makes this animal a good model to study the effect of agro-industrial by-products addition into diet. Therefore, the objective of the present study, as a preliminary research, was to investigate the effect of dietary vinasse on performance, rumen fermentation, blood metabolites, carcass traits and meat chemical composition in Mahabadi goat male kids.

\section{Material and methods}

\section{Animals and diets}

The protocol for this study was approved by the Institutional Animal Care and Use Committee of the University of Tehran (Tehran, Iran). Thirty two Mahabadi goat male kids (average body weight
Table 1. Ingredients and chemical composition of control and vinasse supplemented diets

\begin{tabular}{|c|c|c|c|c|}
\hline \multirow{2}{*}{ Indices } & \multicolumn{4}{|c|}{ Treatments $^{1}$} \\
\hline & $\mathrm{T} 1$ & $\mathrm{~T} 2$ & T3 & T4 \\
\hline \multicolumn{5}{|c|}{ Ingredients, as $\%$ on DM basis } \\
\hline alfalfa hay & 12.94 & 12.94 & 12.94 & 12.95 \\
\hline maize silage & 14.38 & 14.38 & 14.38 & 14.38 \\
\hline wheat straw & 2.73 & 2.73 & 2.73 & 2.73 \\
\hline maize grain & 7.62 & 7.62 & 7.63 & 7.62 \\
\hline barley grain & 36.38 & 36.08 & 35.85 & 35.73 \\
\hline soybean meal & 3.59 & 3.45 & 3.18 & 3.01 \\
\hline wheat bran & 12.80 & 12.07 & 11.13 & 9.83 \\
\hline urea & 0.32 & 0.21 & 0.12 & 0 \\
\hline calcium carbonate & 1.31 & 0.86 & 0.40 & 0 \\
\hline sodium bicarbonate & 0.88 & 0.88 & 0.88 & 0.88 \\
\hline $\begin{array}{l}\text { vitamin mineral } \\
\text { premix }^{2}\end{array}$ & 0.60 & 0.60 & 0.60 & 0.60 \\
\hline salt & 0.29 & 0.29 & 0.29 & 0.29 \\
\hline vinasse & 0 & 4.02 & 8.01 & 12.00 \\
\hline molasses & 6.18 & 3.88 & 1.86 & 0 \\
\hline \multicolumn{5}{|l|}{ Chemical composition, \% } \\
\hline DM & 64.79 & 63.29 & 62.01 & 60.89 \\
\hline $\mathrm{CP}$ & 13.93 & 13.97 & 14.07 & 14.16 \\
\hline EE & 2.20 & 2.20 & 2.20 & 2.20 \\
\hline NDF & 30.30 & 29.96 & 29.29 & 28.54 \\
\hline ash & 8.18 & 8.80 & 9.19 & 9.28 \\
\hline calcium & 1.95 & 1.90 & 1.84 & 1.81 \\
\hline phosphorus & 0.91 & 0.93 & 0.94 & 0.95 \\
\hline sodium & 0.48 & 0.57 & 0.66 & 0.75 \\
\hline potassium & 1.29 & 1.50 & 1.73 & 1.94 \\
\hline magnesium & 0.39 & 0.40 & 0.40 & 0.41 \\
\hline chloride & 0.51 & 0.57 & 0.64 & 0.61 \\
\hline ME, Mcal/kg DM & 2.55 & 2.49 & 2.54 & 2.52 \\
\hline
\end{tabular}

DM - dry matter; CP - crude protein; EE - ether extract; NDF - neutral detergent fiber; ME - metabolizable energy; ${ }^{1}$ treatments: T1 - control diet with no vinasse added, T2 - diet containing 4\% vinasse as DM basis, T3 - diet containing $8 \%$ vinasse as DM basis and T4 - diet containing $12 \%$ vinasse as DM basis; ${ }^{2}$ premix contained: IU/kg: vitamin A 600,000, vitamin D 200,000; $\mathrm{mg} / \mathrm{kg}$ : vitamin E 200, antioxidant 2500, Mg 21 000, Mn 2200, Fe 3000, Cu 300, Zn 300, Co 100, I 120, Se 1.1; g/kg: Ca 195, P 80

(BW) of $20 \pm 2 \mathrm{~kg}$ and age from 5 to 6 months) were divided into 4 groups $(n=8)$ in a complete randomized design and housed in individual pens. Treatments were: a control diet with no vinasse added (T1) and three diets containing 4 (T2), 8 (T3) and $12 \%$ (T4) of vinasse on DM basis. Ingredients and chemical composition of diets are shown in Table 1. Diets were isoenergetic and isonitrogenous, and formulated to meet or exceed nutrient requirement stipulated by National Research Council (NRC, 2007). Vinasse mainly substituted molasses in the diets and the chemical composition of vinasse is shown in Table 2. The beet-vinasse was purchased 
Table 2. Chemical composition of vinasse, as $\%$ on dry matter basis

\begin{tabular}{ll}
\hline Indices & $\%$ \\
\hline Dry matter & 50.54 \\
Crude protein & 27.68 \\
Ash & 23.20 \\
Calcium & 2.98 \\
Phosphorous & 0.80 \\
Sodium & 3.01 \\
Potassium & 8.84 \\
Chloride & 3.20 \\
Glycerol & 3.35 \\
Betaine & 3.73 \\
\hline
\end{tabular}

from Bidestan Alcohol and Foodstuff Production Company located in Qazvin province of Iran.

Kids had free access to fresh water and were adapted to the experimental diets during the first 15 days of trial. Diets were offered ad libitum in equal amounts as total mixed ration twice a day (08:00 and 17:00). Amounts of feed offered and refused were recorded daily and kids were weighed every 21 days during the 90-day experimental period in order to determine the average daily gains (ADG) and FCR.

\section{Blood and rumen fluid sampling and analyses}

In order to analyse plasma, from each kid one blood sample was collected every 21 days ( 4 samples from each kid during the whole experimental period) from the jugular vein into heparinized tubes $3 \mathrm{~h}$ after morning feeding (10:00-11:00), and then immediately placed in iced water. The samples were centrifuged at $3000 \mathrm{rpm}$ for $15 \mathrm{~min}$. The obtained plasma was aliquoted in $1.5-\mathrm{ml}$ microtubes and stored at $-20{ }^{\circ} \mathrm{C}$ until further analyses. After the experimental period, the plasma samples were thawed and concentrations of glucose, albumin, total protein, urea, calcium, phosphorus, magnesium and potassium were determined via an automated enzymatic colorimetric principle using test kits (Pars Azmoon, Tehran, Iran) and a spectrophotometer Shimadzu UV-VIS 160 (Shimadzu, Tokyo, Japan).

Rumen fluid sampling was performed by a rumen tube technique (Ramos-Morales et al., 2014) on days 64 and 90 from each kid before morning feeding to determine fermentation parameters including rumen $\mathrm{pH}$, and ammonia and volatile fatty acids (VFAs) concentration. After collection, ruminal contents were strained through 4 layers of cheesecloth and analysed for $\mathrm{pH}$ using a portable $\mathrm{pH}$ meter (Model 265A; Orion Research Inc., Beverly, MA, USA). A 5-ml subsample of strained ruminal fluid was mixed with chilled $25 \%$ meta-phosphoric $\operatorname{acid}\left(\mathrm{H}_{2} \mathrm{PO}_{4}\right)$ and another 5-ml subsample was mixed with $1 \% \mathrm{H}_{2} \mathrm{SO}_{4}$, both stored at $-20{ }^{\circ} \mathrm{C}$ for later determination concentration of VFAs and ammonia-N $\left(\mathrm{NH}_{3} \mathrm{~N}\right.$ ), respectively (Gozho and Mutsvangwa, 2008). At the end of the experiment, frozen ruminal fluid subsamples were thawed at room temperature and then centrifuged. Ruminal VFAs were separated and quantified by gas chromatography (Varian 3700; Varian Specialties Ltd., Brockville, Ontario, Canada) with a $15-\mathrm{m}(0.53 \mathrm{~mm}$ i.d. $)$ fused silica column (DBFFAP column; J and W Scientific, Folsom, CA, USA) according to Ottenstein and Bartley (1971). The ammonia concentration in ruminal samples was determined using the colorimetric method described by Weatherburn (1967).

\section{Slaughter and sampling}

Kids were slaughtered after 3 months of trial. Prior to slaughter for 14 to $16 \mathrm{~h}$, they had access only to water. The live weight was recorded before slaughter. After slaughter, the carcasses were split sagittally and weighed to obtain hot carcass weight and graded to determine $12^{\text {th }}$ rib backfat thickness and amount of internal fat (the total weight of physically separable fat from around the pelvis, heart and gastrointestinal tract, as $\mathrm{kg}$ ). The right sides were quartered between the $12^{\text {th }}$ and $13^{\text {th }}$ rib and the longissimus muscle (LM) area was measured between these ribs by tracing of LM using acetate paper according to the procedure of Naumann et al. (1951). The $12^{\text {th }}$ ribs were obtained from the right side of each carcass and used for meat composition analysis; briefly the soft tissues and bones were physically separated from rib and the residuals were minced separately three times in a meat grinder and analysed for moisture, CP, ether extract (EE) and ash according to the procedures of AOAC (1990).

\section{Statistical analysis}

The data were subjected to analysis of variance (ANOVA) with the inclusion amount of vinasse in the ration as the fixed effect and the animal as the random effect using the MIXED procedure of SAS Software ver. 9.3 (Statistical Analysis System Institute, Cary, NC, USA). Tukey's test was used to evaluate differences among means and significant differences were declared at $P \leq 0.05$.

\section{Results and discussion}

\section{Animal performance}

Dietary supplementation of vinasse had no significant effect on DMI $(P=0.21)$, final BW $(P=0.93)$ and ADG $(P=0.21)$ (Table 3$)$. 
Table 3. Performance characteristics of goat male kids fed graded levels of vinasse, $n=8$ in each treatment

\begin{tabular}{|c|c|c|c|c|c|c|}
\hline \multirow{2}{*}{ Indices } & \multicolumn{4}{|c|}{ Treatments $^{1}$} & \multirow{2}{*}{ SEM } & \multirow{2}{*}{$P$-value } \\
\hline & $\mathrm{T} 1$ & $\mathrm{~T} 2$ & T3 & $\mathrm{T} 4$ & & \\
\hline $\begin{array}{l}\text { Initial body weight, } \\
\text { kg }\end{array}$ & 20.4 & 20.5 & 20.7 & 20.7 & 1.831 & 0.80 \\
\hline $\begin{array}{l}\text { Final body weight, } \\
\mathrm{kg}\end{array}$ & 30.1 & 29.2 & 28.5 & 29.5 & 1.593 & 0.93 \\
\hline $\begin{array}{l}\text { Average daily gain, } \\
\text { g/day }\end{array}$ & 129 & 119 & 106 & 118 & 11.429 & 0.61 \\
\hline $\begin{array}{l}\text { Dry matter (DM) } \\
\text { intake, g/day }\end{array}$ & 1017 & 917 & 892 & 945 & 41.063 & 0.21 \\
\hline $\begin{array}{l}\text { Feed conversion } \\
\text { ratio, } \mathrm{g} / \mathrm{g}\end{array}$ & 7.9 & 8.1 & 8.6 & 8.2 & 0.530 & 0.79 \\
\hline \multicolumn{7}{|c|}{$\begin{array}{l}1 \text { treatments: T1 - control diet with no vinasse added, T2 - diet } \\
\text { containing } 4 \% \text { vinasse as DM basis, T3 - diet containing } 8 \% \text { vinasse } \\
\text { as DM basis and T4 - diet containing } 12 \% \text { vinasse as DM basis; } \\
\text { a-b - different superscripts following means in the same row indicate } \\
\text { differences at } P \leq 0.05 \text {; SEM - standard error of mean }\end{array}$} \\
\hline
\end{tabular}

Also, the obtained results showed that FCR was similar among treatments $(P=0.79)$. There is no available data about the use of vinasse in goat male kid feeding, but according to Yalçın et al. (2010) who used modified dried vinasse (ProMass) in steer diet at the proportion of 40 or $80 \mathrm{~g} / \mathrm{kg}$ DM of ration, there was also no significant improvement in the steer performance. Similarly, Potter et al. (1985) reported that $5 \%$ vinasse addition in the diet of steer had no effect on animal performance. Similarly, ADG, final BW and FCR of fattening lambs were not influenced by addition of molasses distillers soluble to the diet (Moeini et al., 2013). Also feeding sugarcane press mud at the level of 10 or $20 \%$ of concentrate had no significant effect on BW and carcass weight in lambs (Kumar et al., 2015).

In contrast to results obtained in the present experiment, Zali et al. (2017) on Holstein male calves and López-Campos et al. (2011) on fattening lambs showed that addition of vinasse to the diet reduced feed intake and growth rate and increased the FCR. However, the supplementation of dried vinasse rice at a dose of $500 \mathrm{~g} / \mathrm{kg} \mathrm{DM}$ in lambs, resulted in higher ADG and lower FCR after 60 days of trial (El-Zaiat et al., 2019). In studies in which the diets were not isoenergetic, the inclusion of vinasse up to $10 \%$ decreased ADG and therefore the FCR, which was attributed partly to the reduced energy content in the diet (Potter et al., 1985). Also, the lack of effect of vinasse on DMI in the present study was consistent with unchanged apparent digestibility of DM and NDF (El-Zaiat et al., 2019).

\section{Characterization of ruminal fermentation}

Vinasse supplementation into diets had no significant effect on rumen fermentation parameters
Table 4. Rumen fermentation parameters of goat male kids fed graded levels of vinasse, $n=16$ in each treatment

\begin{tabular}{|c|c|c|c|c|c|c|}
\hline \multirow{2}{*}{ Indices } & \multicolumn{4}{|c|}{ Treatments $^{1}$} & \multirow{2}{*}{ SEM } & \multirow{2}{*}{$P$-value } \\
\hline & $\mathrm{T} 1$ & $\mathrm{~T} 2$ & T3 & T4 & & \\
\hline$\overline{\mathrm{pH}}$ & $6.54^{b}$ & $6.61^{b}$ & $6.92^{\mathrm{a}}$ & $6.89^{\mathrm{a}}$ & 0.094 & 0.03 \\
\hline $\begin{array}{l}\text { Ammonia nitrogen, } \\
\mathrm{mg} / \mathrm{dl}\end{array}$ & 8.42 & 10.6 & 8.99 & 8.99 & 1.231 & 0.62 \\
\hline Total VFA, mmol/l & 48.1 & 55.8 & 47.6 & 51.2 & 6.758 & 0.83 \\
\hline Acetic acid, \% & 67.3 & 68.0 & 69.3 & 68.6 & 1.450 & 0.80 \\
\hline Propionic acid, \% & 18.6 & 15.1 & 15.4 & 17.5 & 1.858 & 0.53 \\
\hline Butyric acid, \% & 13.2 & 16.0 & 14.1 & 12.6 & 1.461 & 0.33 \\
\hline Valeric acid, \% & 0.33 & 0.37 & 0.51 & 0.34 & 0.120 & 0.71 \\
\hline Isovaleric acid, \% & 0.58 & 0.48 & 0.54 & 0.77 & 0.084 & 0.12 \\
\hline $\begin{array}{l}\text { Acetate/propionate } \\
\text { ratio }\end{array}$ & 4.16 & 4.53 & 4.52 & 3.93 & 0.371 & 0.62 \\
\hline
\end{tabular}

${ }^{1}$ treatments: $\mathrm{T} 1$ - control diet with no added vinasse, T2 - diet containing $4 \%$ vinasse as DM basis, T3 - diet containing $8 \%$ vinasse as DM basis and T4-dietcontaining $12 \%$ vinasse as DM basis, ${ }^{\text {a-b }}$-different superscripts following means in the same row indicate differences at $P \leq 0.05$; SEM - standard error of mean; VFA - volatile fatty acids

including VFAs $(P>0.05)$ and ammonia $(P=0.62)$ concentrations, except rumen $\mathrm{pH}$ which was increased as the level of vinasse increased in the kids $\operatorname{diet}(P=0.03$, Table 4$)$.

The obtained results are in line with those of Fernández et al. (2009) who observed that dietary inclusion of vinasse had no significant effect on rumen fermentation parameters including VFAs and ammonia concentrations in ewes. On the other hand, the results are in disagreement with the results of our previous study conducted on growing calves (Zali et al., 2017); although we used the same source of vinasse and relatively similar levels (5, 10 and $15 \%$ on DM basis). The Zali et al. (2017) showed that propionate and total VFAs concentration significantly decreased and ruminal $\mathrm{NH}_{3} \mathrm{~N}$ remained unchanged. Also, feeding vinasse in steers at the level of 10 and $15 \%$ reduced ruminal propionic acid concentration and increased butyric acid (Potter et al., 1985).

In some studies where vinasse was used in the diet, change in FCR was related to change in VFAs profile in the rumen (Chalupa, 1980). However, the concentration of VFAs was unchanged in the current study and therefore FCR remained unchanged.

Higher concentration of potassium as an alkali mineral in vinasse can contribute to greater rumen $\mathrm{pH}$ value (Zali et al., 2017) and is in agreement with the results of López-Campos et al. (2011) and Karalazos and Swan (1977). However, in later studies, higher $\mathrm{pH}$ value was attributed to lower DMI and consequently lower consumption of concentrate as a consequence of vinasse supplementation (López-Campos et al., 2011). 
Table 5. Plasma metabolites of goat male kids fed graded levels of vinasse, $n=32$ in each treatment

\begin{tabular}{lcccccc}
\hline \multirow{2}{*}{ Indices } & \multicolumn{2}{c}{ Treatments $^{1}$} & & & \multirow{2}{*}{ SEM } & P-value \\
\cline { 2 - 6 } & T1 & T2 & T3 & T4 & & \\
\hline Glucose, mg/dl & 66.5 & 67.2 & 64.8 & 67.8 & 2.291 & 0.83 \\
Albumin, g/l & 2.88 & 2.75 & 2.87 & 2.93 & 0.111 & 0.87 \\
Total protein, g/l & 8.45 & 8.30 & 8.60 & 8.52 & 0.249 & 0.89 \\
Urea, mmol/l & 13.8 & 13.7 & 14.5 & 15.3 & 2.033 & 0.87 \\
Calcium, mg/dl & 9.59 & 9.75 & 9.11 & 9.77 & 0.254 & 0.29 \\
Phosphorus, mg/dl & 7.40 & 8.06 & 8.00 & 7.70 & 0.737 & 0.91 \\
Magnesium, mg/dl & $1.20^{\mathrm{b}}$ & $2.03^{\mathrm{a}}$ & $2.03^{\mathrm{a}}$ & $2.00^{\mathrm{ab}}$ & 0.012 & 0.03 \\
Potassium, mg/dl & 2.35 & 2.39 & 1.97 & 2.00 & 0.218 & 0.49 \\
\hline
\end{tabular}

${ }^{1}$ treatments: T1 - control diet with no vinasse added, T2 - diet containing $4 \%$ vinasse as DM basis, T3 - diet containing $8 \%$ vinasse as DM basis and T4 - diet containing $12 \%$ vinasse as DM basis; ${ }^{\mathrm{a}-\mathrm{b}}$ - different superscripts following means in the same row indicate differences at $P \leq 0.05$; SEM - standard error of mean

\section{Blood metabolites}

No significant changes in plasma metabolites such as glucose $(P=0.83)$, albumin $(P=0.87)$, total protein $(P=0.89)$ and urea nitrogen $(P=0.87)$ concentrations were observed during the experiment (Table 5). Also, vinasse supplementation had no significant effect on plasma concentration of minerals including calcium $(P=0.29)$, phosphorus $(P=0.91)$ and potassium $(P=0.49)$, except for magnesium level which increased significantly $(P=0.03)$ as the level of vinasse increased in the ration.

Such results confirm the results of the study of Moeini et al. (2013), who observed that dietary inclusion of molasses distillers soluble had no significant effect on blood metabolites including glucose, cholesterol, triglycerides, urea, creatinine and albumin concentrations as well as on serum concentrations of minerals including sodium, potassium, calcium and phosphorus.

Supplementation of vinasse in ruminant diet had contrary effects on plasma metabolites including enhancement of plasma ammonia concentration (Karalazos and Swan, 1977), reduction of glucose and ammonia concentration (López-Campos et al., 2011), and showed no effects on plasma metabolites (Yalçın et al., 2010). In the later study, the use of modified dried vinasse (ProMass) in steers nutrition at the level of 40 or $80 \mathrm{~g} / \mathrm{kg} \mathrm{DM}$ of ration did not affect blood biochemical parameters (Yalçın et al., 2010).

It has been reported that dietary supplementation of vinasse up to $20 \%$ increases plasma urea nitrogen through reducing fermentable energy in the rumen (Karalazos and Swan, 1977), but in the present study the highest level of vinasse was much lower $(12 \%)$. On the other hand, because blood urea is an important index of the protein status in ruminants and the plasma urea nitrogen concentration is related to the level of ammonia absorption from the rumen wall and/or the deamination of amino acids not deposited in the tissue (Deaville and Galbraith, 1992), the absence of its significant variations in supplemented kids may suggest that ammonium produced throughout vinasse protein degradation in rumen is efficiently converted for microbial protein synthesis. Furthermore, the stability of the serum biochemical profiles can suggest that no major biochemical pathway was affected by vinasse supplementation in goat kids (Yalçın et al., 2010). The lack of difference in some plasma metabolites including glucose and ammonia in the current study can be explained by diets formulation which was isoenergetic and had the same percentage of cereals and protein fractions. In addition, rumen ammonia and propionate concentrations which have the major effect on plasma ammonia and glucose concentrations were not affected in the current study too.

\section{Carcass measurements and meat chemical composition}

In the present study, no significant effects on carcass characteristics including hot carcass weight $(P=0.75)$, carcass yield $(P=0.81), \mathrm{LM}$ area $(P=0.97)$ and backfat thickness $(P=0.68)$ were observed. However, kids that were fed 8 or $12 \%$ vinasse containing diets numerically had heavier carcasses in comparison to those fed the control diet. In addition, a significant decline was observed in internal fat content as the level of vinasse increased $(P=0.04$, Table 6$)$.

Table 6. Carcass characteristics and longissimus muscle (LM) composition in goat male kids fed graded levels of vinasse, $n=8$ in each treatment

\begin{tabular}{|c|c|c|c|c|c|}
\hline \multirow{2}{*}{ Indices } & \multicolumn{4}{|c|}{ Treatments ${ }^{1}$} & \multirow{2}{*}{ - SEM $P$-value } \\
\hline & $\overline{\mathrm{T} 1}$ & T2 & T3 & T4 & \\
\hline Hot carcass weight, $\mathrm{kg}$ & 12.6 & 12.1 & 13.1 & 13.6 & 0.9880 .75 \\
\hline Carcass yield, $\%$ & 40.8 & 40.2 & 42.5 & 41.5 & 1.6910 .81 \\
\hline Internal fat, kg & $0.26^{\mathrm{ab}}$ & b $0.33^{a}$ & $0.17^{b}$ & $0.13^{b}$ & 0.0420 .02 \\
\hline LM area, $\mathrm{cm}^{2}$ & 14.5 & 15.2 & 13.7 & 14.9 & 2.2740 .97 \\
\hline Backfat thickness, mm & 1.64 & 1.27 & 1.43 & 1.52 & 0.3080 .68 \\
\hline \multicolumn{6}{|c|}{ LM chemical composition, \% } \\
\hline dry matter & 25.4 & 25.6 & 25.3 & 25.6 & 0.5410 .97 \\
\hline crude protein & 20.9 & 20.3 & 20.3 & 20.8 & 0.2440 .18 \\
\hline ether extract & 3.37 & 3.67 & 3.57 & 3.50 & 0.3100 .93 \\
\hline ash & 1.48 & 1.21 & 1.33 & 1.45 & 0.1030 .21 \\
\hline
\end{tabular}

1 treatments: T1 - control diet with no vinasse added, T2 - diet containing $4 \%$ vinasse as DM basis, T3 - diet containing $8 \%$ vinasse as DM basis and T4 - diet containing $12 \%$ vinasse as DM basis; a-b - different superscripts following means in the same row indicate differences at $P \leq 0.05$; SEM - standard error of mean 
In agreement with these results, feeding vinasse at the level of 5, 10 and 15\% (DM basis) had no significant effect on carcass characteristics (Potter et al., 1985). Also, Zali et al. (2017) observed that vinasse supplementation of growing calves significantly reduced subcutaneous and internal fat. Yalçın et al. (2010) reported that fat deposits, mainly heart and pelvic fats, were significantly reduced when the modified dried vinasse (ProMass) was used in steer diet at the proportion of 40 or $80 \mathrm{~g} / \mathrm{kg} \mathrm{DM}$ of ration.

Similarly, in steers Potter et al. (1985) reported that supplementation of $50 \mathrm{~g} / \mathrm{kg}$ vinasse had no significant alterations of carcass traits, while leaner carcasses from steers supplemented with $100 \mathrm{~g} / \mathrm{kg}$ vinasse and significant reduction of the internal fat were noted. Also in the study of Kumar et al. (2015), feeding sugarcane press mud at the level of 10 or $20 \%$ of concentrate had no significant effect on yield of visceral organs and chemical composition of longissimus dorsi muscle.

Fernández et al. (2000) demonstrated that betaine supplementation significantly reduced the subcutaneous fat at the $12^{\text {th }}$ and $13^{\text {th }}$ rib in female lambs. High betaine content in vinasse, as a lipolytic agent, is probably responsible for the reduction in fat deposition in meat producing animals (Fernández et al., 2000). Moreover, it has been shown that betaine has a positive effect on protein metabolism (Puchala et al., 1995).

In the present study, the examined treatments exerted no significant effect on LM meat chemical composition including $\mathrm{DM}(P=0.97), \mathrm{EE}(P=0.93)$, $\mathrm{CP}(P=0.18)$ and ash percent $(P=0.21)$ (Table 6). However, the results of our previous study on calves (Zali et al., 2017) and Yalçın et al. (2010) on steers, showed that supplementationwith condensedmolasses solubles resulted in leaner carcasses and significant reduction of meat ether extract percent, which can be also related to betaine content in vinasse (Fernández et al., 2000). In ruminants, most of the betaine is degraded by microorganisms in the forestomaches, but some might avoid rumen degradation and, after absorption, can be used a source of methyl groups in tissue metabolism (Wang et al., 2010).

\section{Conclusions}

The supplementation of vinasse up to $12 \%$ (dry matter basis) in the diet had no deleterious effects on growth performance of goat male kids, and its effects on carcass characteristics, and rumen and blood parameters were negligible. However, the sample size ( 8 goats per treatment) was small.
Thus, prior to the practical adoption of the current findings, further trials with larger sample size and wider scope of experimental conditions are suggested.

\section{Funding}

The present article was extracted from the research project that was financially supported by Iran National Science Foundation - Science Deputy of Presidency, grant No. 89001972.

\section{References}

AOAC (Association of Official Analytical Chemists), 1990. Official Methods of Analysis of the Association of Official Analytical Chemists. $15^{\text {th }}$ Edition. Arlington, VA (USA)

Cazetta M.L., Celligoi M.A.P.C., 2006. Study of molasses/ vinasse waste ratio for single cell protein and total. lipids production by microorganisms (in Spanish: Estudo de diferentes combinações de melaço/ vinhaça como substrato para produção de proteínas e lipídios por microrganismos. Ciên. Exatas Tecnol. 27, 3-10, https://doi.org/10.5433/1679-0375.2006v27n1p3

Chalupa W., 1980. Chemical control of rumen microbial metabolism. In: Y. Ruckebusch, P. Thivend (Editors). Digestive Physiology and Metabolism in Ruminants. MTP Press Limited, Falcon House. Lancaster (UK), pp. 325-347, https://doi.org/10.1007/978-94011-8067-2_16

Deaville E.R., Galbraith H., 1992. Effect of dietary protein level and yeast culture on growth, blood prolactin and mohair fibre characteristics of British Angora goats. Anim. Feed. Sci. Technol. 38, 123-133, https://doi.org/10.1016/03778401(92)90097-P

Elferink E.V., Nonhebel S., Moll H.C., 2008. Feeding livestock food residue and the consequences for the environmental impact of meat. J. Clean. Prod. 16, 1227-1233, https://doi. org/10.1016/j.jclepro.2007.06.008

El-Zaiat H.M., Ré D.D., Patino H.O., Sallam S.M.A., 2019. Assessment of using dried vinasse rice to replace soybean meal in lambs diets: In vitro, lambs performance and economic evaluation. Small Ruminant Res. 173, 1-8, https://doi.org/10.1016/j. smallrumres.2019.01.003

Fernández B., Bodas R., López-Campos Ó., Andrés S., Mantecón A.R., Giráldez F.J., 2009. Vinasse added to dried sugar beet pulp: Preference rate, voluntary intake, and digestive utilization in sheep. J. Anim. Sci. 87, 2055-2063, https://doi.org/10.2527/ jas.2008-1550

Fernández C., López-Saez A., Gallego L., de la Fuente J.M., 2000. Effect of source of betaine on growth performance and carcass traits in lambs. Anim. Feed. Sci. Technol. 86, 71-82, https://doi.org/10.1016/S0377-8401(00)00150-4

Gozho G.N., Mutsvangwa T., 2008. Influence of carbohydrate source on ruminal fermentation characteristics, performance, and microbial protein synthesis in dairy cows. J. Dairy Sci. 91, 2726-2735, https://doi.org/10.3168/jds.2007-0809

Karalazos A., Swan H., 1977. The nutritional value for sheep of molasses and condensed molasses solubles. Anim. Feed. Sci. Technol. 2, 143-152, https://doi.org/10.1016/03778401(77)90015-3

Kumar R., Saha S.K., Mendiratta S.K., 2015. Effect of feeding sugarcane press mud on carcass traits and meat quality characteristics of lambs. Vet. World 8, 793-797, https://doi. org/10.14202/vetworld.2015.793-797 
López-Campos Ó., Bodas R., Prieto N., Frutos P., Andrés S., Giráldez F.J., 2011. Vinasse added to the concentrate for fattening lambs: intake, animal performance, and carcass and meat characteristics. J. Anim. Sci. 89, 1153-1162, https://doi. org/10.2527/jas.2010-2977

Moeini M.M., Veyskarami S., Hozhabri F., 2014. Effect of molasses distillers condensed soluble on nutrients digestibility, performance and Ssome blood biological parameters in lambs. Ann. Res. Rev. Biol. 4, 443-450, https://doi. org/10.9734/ARRB/2014/5482

Naumann H.D., 1951. A recommended procedure for measuring and grading beef for carcass evaluation. Proc. Recip. Meat Conf. 4, 89-99

NRC (National Research Council), 2007. Nutrient Requirements of Small Ruminants: Sheep, Goats, Cervids, and New World Camelids. The National Academies Press. Washington, DC (USA), https://doi.org/10.17226/11654

Ottenstein D.M., Bartley D.A., 1971. Improved gas chromatography separation of free acids $\mathrm{C} 2-\mathrm{C} 5$ in dilute solution. Anal. Chem. 43, 952-955, https://doi.org/10.1021/ac60302a043

Potter S.G., Moya A., Henry P.R., Palmer A.Z., Becker H.N., Ammerman C.B., 1985. Sugarcane condensed molasses solubles as a feed ingredient for finishing cattle. J. Anim. Sci. 60, 839-846, https://doi.org/10.2527/jas1985.603839x

Puchala R., Sahlu T., Herselman M.J., Davis J.J., 1995. Influence of betaine on blood metabolites of Alpine and Angora kids. Small Ruminant Res. 18, 137-143, https://doi.org/10.1016/09214488(95)00725-Z

Ramos-Morales E., Arco-Pérez A., Martín-García A.l., YáñezRuiz D.R., Frutos P., Hervás G., 2014. Use of stomach tubing as an alternative to rumen cannulation to study ruminal fermentation and microbiota in sheep and goats. Anim. Feed. Sci. Technol. 198, 57-66, https://doi.org/10.1016/j. anifeedsci.2014.09.016

Russ W., Meyer-Pittroff R., 2004. Utilizing waste products from the food production and processing industries. Crit. Rev. Food. Sci. Nutr. 44, 57-62, https://doi.org/10.1080/10408690490263783
Stemme K., Gerdes B., Harms A., Kamphues J., 2005. Beet-vinasse (condensed molasses solubles) as an ingredient in diets for cattle and pigs - nutritive value and limitations. J. Anim. Physiol. Anim. Nutr. 89, 179-183, https://doi.org/10.1111/ j.1439-0396.2005.00554.x

Tufarelli V., Introna M., Cazzato E., Mazzei D., Laudadio V., 2013. Suitability of partly destoned exhausted olive cake as byproduct feed ingredient for lamb production. J. Anim. Sci. 91, 872-877, https://doi.org/10.2527/jas.2012-5541

Tufarelli V., Laudadio V., 2011. Effect of wheat middlings-based total mixed ration on milk production and composition responses of lactating dairy ewes. J. Dairy Sci. 94, 376-381, https://doi. org/10.3168/jds.2010-3496

Vasta V., Nudda A., Cannas A., Lanza M., Priolo A., 2008. Alternative feed resources and their effects on the quality of meat and milk from small ruminants. Anim. Feed. Sci. Technol. 147, 223-246, https://doi.org/10.1016/j.anifeedsci.2007.09.020

Wang C., Liu Q., Yang W.Z., Wu J., Zhang W.W., Zhang P., Dong K.H., Huang Y.X., 2010. Effects of betaine supplementation on rumen fermentation, lactation performance, feed digestibilities and plasma characteristics in dairy cows. J. Agric. Sci. 148, 487-495, https://doi.org/10.1017/S0021859610000328

Weatherburn M.W., 1967. Phenol-hypochlorite reaction for determination of ammonia. Anal. Chem. 39, 971-974, https:// doi.org/10.1021/ac60252a045

Weigand E., Kirchgessner M., 1980. Protein and energy value of vinasse for pigs. Anim. Feed. Sci. Technol. 5, 221-231, https://doi.org/10.1016/0377-8401(80)90032-2

Yalçın S.K., Eltan Ö., Karslı M.A., 2010. The nutritive value of modified dried vinasse (ProMass) and its effects on growth performance, carcass characteristics and some blood biochemical parameters in steers. Revue Méd. Vét. 161, 245-252

Zali A., Eftekhari M., Fatehi F., Ganjkhanlou M., 2017. Effect of vinasse (condensed molasses solubles) on performance and meat chemical composition of Holstein male calves. Ital. J. Anim. Sci. 16, 515-520, https://doi.org/10.1080/182805 1X.2017.1298407 